
Not for reproduction, distribution or commercial use.

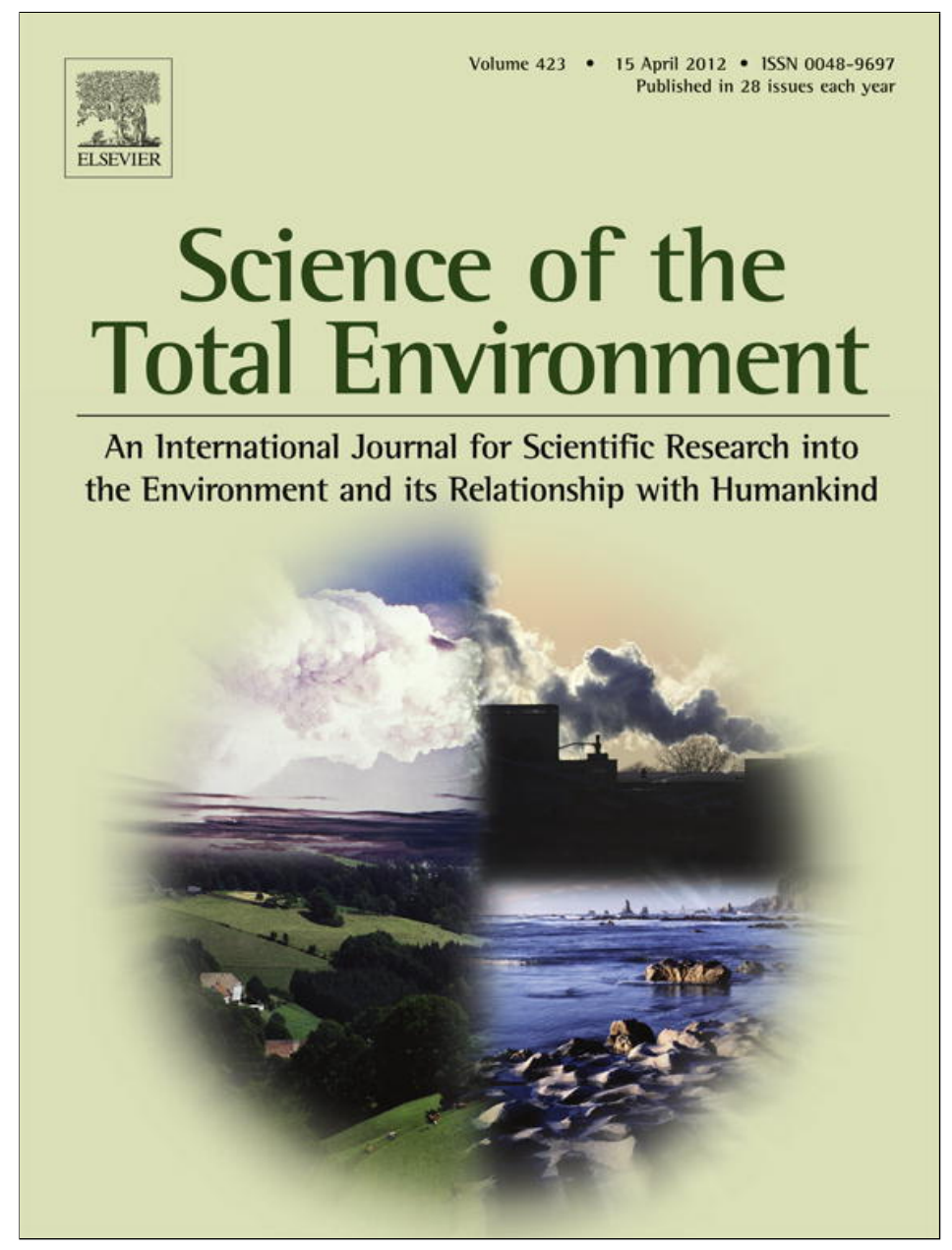

This article appeared in a journal published by Elsevier. The attached copy is furnished to the author for internal non-commercial research and education use, including for instruction at the authors institution and sharing with colleagues.

Other uses, including reproduction and distribution, or selling or licensing copies, or posting to personal, institutional or third party websites are prohibited.

In most cases authors are permitted to post their version of the article (e.g. in Word or Tex form) to their personal website or institutional repository. Authors requiring further information regarding Elsevier's archiving and manuscript policies are encouraged to visit:

http://www.elsevier.com/copyright 


\title{
Potential impact of fertilization practices on human dietary intake of dioxins in Belgium
}

\author{
P. Dumortier ${ }^{\text {a }}$, M. Elskens ${ }^{\text {b }}$, J.F. Focant ${ }^{\text {c }}$, L. Goeyens ${ }^{\text {b }}$, K. Vandermeiren ${ }^{\text {a }}$, L. Pussemier ${ }^{\text {a,* }}$ \\ a CODA-CERVA, Veterinary and Agrochemical Research Center, Operational Directorate Chemical safety of the Food Chain, Leuvensesteenweg 17, B-3080 Tervuren, Belgium \\ b Vrije Universiteit Brussel, Pleinlaan 2, B-1050 Elsene, Belgium \\ c CART, Mass Spectrometry Laboratory, Organic and Biological Analytical Chemistry, Chemistry Department, University of Liège, Allée de la Chimie 3, B-6c Sart-Tilman, \\ B-4000 Liège, Belgium
}

\section{A R T I C L E I N F O}

\section{Article history:}

Received 30 September 2011

Received in revised form 3 February 2012

Accepted 4 February 2012

Available online 7 March 2012

\section{Keywords:}

Dioxin

Fertilizer

Sludge

Belgium

Food chain

Risk assessment

\begin{abstract}
A B S T R A C T
Dioxins can enter the food chain at any stage, including crop fertilization. Therefore, we developed a simple method for estimating the introduction of dioxins in the food chain according to various fertilization practices. Using dioxin's contamination data taken from the literature, we estimated that fertilization accounts for approximately $20 \%$ of the dioxin inputs on agricultural soils at country scale. For the estimations at the field scale, 6 fertilization scenarios were considered: sludge, compost, digestate, manure, mineral fertilizers, and a common fertilization scenario that corresponds to an average situation in Belgium and combines mineral and organic fertilizers. According to our first estimations, mineral fertilizers, common fertilization practices or manure bring less than $1 \mathrm{ng} \mathrm{TEQ} / \mathrm{m}^{2}$ while atmospheric deposition or digestate bring between 1 and $3 \mathrm{ng} \mathrm{TEQ} / \mathrm{m}^{2}$ and sludge or compost bring more than $3 \mathrm{ng} \mathrm{TEQ} / \mathrm{m}^{2}$. The use of solid fertilizers could potentially increase the dioxin levels in the $30 \mathrm{~cm}$ agricultural soil layer by 0 to $\sim 1.5 \%$ per year (up to $9 \%$ for the $5 \mathrm{~cm}$ thick surface layer). For animals, the increase in dioxin ingestion linked to the fertilization practices is lower than $1 \%$ for most scenarios with the exception of the compost scenario. Increases in human dietary intake of dioxin are estimated to be lower than $1 \%$ for conventional rearing methods (i.e. grazing animals are reared outdoor while pigs and poultry are reared indoor). Spraying liquid fertilizers on meadows and fodder crops, even if very limited in practice, deserves much more attention because this application method could theoretically lead to higher dioxin's intake by livestock (from 6 to $300 \%$ ). Considering an average half-life of dioxins in soils of 13 years, it appears that the risks of accumulation in soils and in the food chain are negligible for the various fertilization scenarios.
\end{abstract}

(c) 2012 Elsevier B.V. All rights reserved.

\section{Introduction}

Polychlorinated dibenzo-p-dioxins (PCDDs), polychlorinated dibenzofurans (PCDFs) and dioxin-like polychlorinated biphenyls (DLPCBs) belong to a class of organic compounds which are referred to as dioxins because they exhibit "dioxin-like toxicity", commonly expressed in toxicological equivalents (TEQ) (Van den Berg et al., 1998; 2006). Human exposure to dioxin is a matter of concern. These compounds cause impairment of the immune system, the nervous system, the endocrine system and the reproductive functions and are also suspected of causing cancer (European Commission, 2010). The World Health Organization recommends considering these compounds as priority contaminants for inclusion in monitoring programs (WHO, 2006).

\footnotetext{
* Corresponding author. Tel.: + 32 2/ 76922 4; fax: + 32 2/ 7692305.

E-mail addresses: pierre.dumortier@coda-cerva.be (P. Dumortier), melskens@vub.ac.be (M. Elskens),JF.Focant@ulg.ac.be (J.F. Focant), lgoeyens@vub.ac.be (L. Goeyens), karine.vandermeiren@coda-cerva.be (K. Vandermeiren), luc.pussemier@coda-cerva.be (L. Pussemier).
}

Dioxins are classified as persistent organic pollutants (POPs) meaning, among others, that they bioaccumulate in the food chain (Stockholm Convention on Persistent Organic Pollutants, 2008). Nevertheless, limited attention is given to the possible incorporation of dioxins into the food chain through the use of agricultural fertilizers. At the same time, some organic fertilizers like sludge or compost are known to contain dioxins while the presence of dioxins in other fertilizers is little documented and cannot be excluded (Brändli et al., 2007; Kupper et al., 2007; Martinez et al., 2007; Van Gestel et al., 2007; Brandling et al., 2005; Zennegg et al., 2005; Fuentes et al., 2007; Brändli et al., 2004; Eljarrat et al., 2003; Groeneveld and Hébert, 2002; Stevens and Jones, 2002; Stevens et al., 2001; Eljarrat et al., 1999; Paulsrud et al., 1999; Rogowski et al., 1999).

In this work we use the term fertilizer to designate any kind of material that is added to the soil to increase the nutrient content or to improve the soil properties, including chemical fertilizers, sludge, compost and soil conditioners. Sludge is the biosolid produced during the purification process of urban waste water, industrial waste water or surface water. Although different in composition, these sludges will be grouped and simply referred to as sludge. 
Currently, no legal limit for dioxin concentration in fertilizers is set by the European legislation. National legislations are more restrictive, often imposing PCB limits and sometimes even PCDD/F limits for biowastes. In Belgium, organic fertilizers must contain less than $0.8 \mathrm{mg}$ PCBs $/ \mathrm{kg} \mathrm{dw}$ for the sum of the seven marker PCBs in the Flemish region (OVAM, 2005) and less than $0.5 \mathrm{mg} \mathrm{PCBs} / \mathrm{kg} \mathrm{dw}$ for the sum of the seven marker PCBs in the Walloon region. No monitoring is done yet for the PCDD/Fs (FPS, 2010, unpublished document).

The present report has two objectives. Firstly, it proposes a simple method to assess the potential impact of fertilization practices on human intake of dioxins. Secondly, the developed method is applied to the Belgian situation as a proof of concept, using data gathered from the literature.

\section{Methods}

\subsection{Concept}

The impact of fertilization practices on the human dioxin intake has already been assessed for sludge (Wild et al., 1994; McLachlan et al., 1996; Rideout and Teschke, 2004) and for the combined use of biological wastes and chemical fertilizers (Fouchécourt and Beausoleil, 2001). Here, we describe a simple method which specifically aims at a comparison of fertilization practices at each step of the method.

In this study, two different scales are considered. At the territory scale, we assess the quantities of dioxin brought by fertilization practices throughout the territory in order to obtain information concerning the whole population. At field scale, we consider the impact of the worst case practices on the human dioxin intake. For each described fertilization practice, the effect on the soil dioxin levels is calculated. Further estimation of the impact on feed- and foodstuffs, as well as on the possible dioxin intake by humans, is carried out.

According to a literature review from the European Commission Joint Research Centre (Erhardt and Prüeß, 2001), four main pathways should be considered when assessing the transfer of POPs from sludge to humans. These are transfer (i) sludge-man by handling, (ii) soil-man (soil ingestion by human), (iii) soil (-plant)-animal and (iv) soil-water. However, here, we are only interested in transfer pathways that are relevant for the general population. Nonoccupational sludge or soil ingestion or inhalation by humans is very unlikely to occur at significant levels. Moreover, Wild et al. (1994) estimated that food accounts for more than 99\% of the human dioxin intake, while the intakes from water and air are negligible. At the same time, if we exclude aquaculture, most of the fish eaten in Belgium is coming from the sea and not from rivers, lakes or ponds (Willemsen, 2003). The increase of the seawater dioxin level caused by fertilizers use, although uncalculated, can be reasonably considered as negligible. Indeed, dioxins are not mobile in soil (lipophilic) and direct water contamination by fertilizers is scarce (only through point contamination). Therefore, it is considered that merely the soil (-plant)-animal pathway is impacted by fertilization practices. The word "plant" is put in brackets because, most of the time, it only serves as a support for soil or fertilizers since dioxin uptake by plants is generally extremely low (Uegaki et al., 2006). In some cases (cucurbitaceae), soil-plant dioxin transfer is of importance but these species are exceptions and are of minor importance for human dioxin intake (Huelster et al., 1994).

Two kinds of fertilization practices are distinguished; solid fertilizers are believed to drop on soil after spreading, resulting in a soil contamination, while liquid fertilizers can be sprayed on plants, stick to leaves and lead to a plant contamination.

The developed method is valid for typical feeding conditions. Involuntary feed contamination by dioxins (e.g. by incorporation of contaminated fat into animal feeds) do not belong to the scope of this paper.

\subsection{Impact at territory scale}

At territory scale, the total amount of dioxins brought to agricultural soils by fertilizing practices is assessed considering for each fertilizer the quantity applied to the entire territory and the estimated TEQ levels (Eq. (1)).

$$
\begin{aligned}
& \text { Amount of dioxins }\left[\frac{\mathrm{ng} \text { TEQ }}{\text { year }}\right] \\
& =\sum\left(\text { Fertilizer consumption }\left[\frac{\mathrm{kg}}{\text { year }}\right] \times \text { Dioxins' concentaration }\left[\frac{\mathrm{ng} \mathrm{TEQ}}{\mathrm{kg}}\right]\right)
\end{aligned}
$$

\subsection{Impact at field scale}

The impact of fertilization practices at field scale is developed in 4 different steps that are described in this section and represented in Fig. 1.

\subsubsection{Identification of fertilizing scenarios}

Six fertilizing scenarios are proposed for solid fertilizers use (manure, sludge, compost, digestate, NPK and common scenario) and four scenarios are proposed for liquid fertilizers sprayed on plants (manure, sludge, digestate and NPK). Each scenario tries to maximize the use of a specific fertilizer while the common scenario represents an average fertilization. The average fertilization is calculated by dividing, for each fertilizer, the known or estimated consumption throughout the territory by the agricultural surface. Liquid fertilizers are not considered in the common scenario because we have no data about the proportion sprayed on plants rather than on soils. By default, these fertilizers are considered to be spread on soils, like solid fertilizers, for the common scenario. Real practices are always combination between these scenarios and will always result in a dioxin transfer lower than the higher value for a specific fertilizer. Over fertilization is not considered in this report because the most common scenario does not imply over fertilization and because the proposed specific scenarios already represent worst case situations (organic fertilizers are scarcely applied at maximum rates in Belgium).

In Belgium, fertilization rates at field scale are limited by federal and regional regulatory constraints. For practical reasons, we regard Belgium as one single entity by considering for each fertilizer the maximum permitted application rate according to the most permissive legislation. The maximum fertilization rates are considered to be equal for solid and for liquid fertilizers. The maximum Nitrogen fertilization rate is 350 or $275 \mathrm{~kg} \mathrm{~N} / \mathrm{ha}$, on Belgian meadows or crops respectively with a maximum of 230 or $170 \mathrm{~kg} \mathrm{~N} / \mathrm{ha}$ provided by organic fertilizers. For sludge, no more than 2 tons dw can be annually applied on meadows and 4 tons dw on crops. The chemical

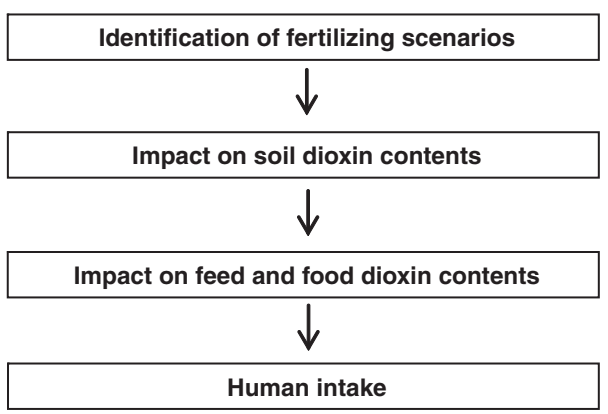

Fig. 1. The four steps' model for assessing the influence of fertilizing practices at field scale on dietary dioxin intake by humans. 
fertilizer scenario only relies on chemical fertilizer use. For the manure, sludge, compost and digestate scenarios, nutrition is then fitted with mineral fertilizers in order to provide, for meadows or crops respectively, a minimum of 350 or $275 \mathrm{~kg} \mathrm{~N} / \mathrm{ha}, 100$ or $85 \mathrm{~kg} \mathrm{P}_{2} \mathrm{O}_{5} / \mathrm{ha}$ and 200 or $300 \mathrm{~kg} \mathrm{~K} \mathrm{~K}_{2} \mathrm{O} / \mathrm{ha}$, considering that $1 \mathrm{~kg}$ chemical fertilizer supplies $1 \mathrm{~kg} \mathrm{~N}$ or $1 \mathrm{~kg} \mathrm{P}_{2} \mathrm{O}_{5}$ or $1 \mathrm{~kg} \mathrm{~K} \mathrm{~K}_{2} \mathrm{O}$ (Nitrawal, 2011; Mestdecreet, 2006; AGW 12/01/95).

For the manure, compost and digestate scenarios, the maximum permitted application rate is determined by the nitrogen content and the maximum permitted nitrogen application rate.

For the common scenario, fertilization rates are provided by descriptive statistics presented in Section 3.

Since no regulations or statistics are available for liming materials, we arbitrarily consider a realistic default input of $850 \mathrm{~kg} / \mathrm{ha}$.

\subsubsection{Determination of the impact of fertilizing practices on the dioxin} content of soils

The total dioxin input on fields is calculated using Eq. (2). For each of the proposed scenarios, fertilizer application rates are multiplied by dioxin levels.

$$
\begin{aligned}
\text { Dioxin input }\left[\frac{\mathrm{ng} \text { TEQ }}{\mathrm{m}^{2}}\right]= & \sum\left(\text { Fertilizer consumption }\left[\frac{\mathrm{kg}}{\mathrm{m}^{2}}\right]\right. \\
& \left.\times \text { Dioxin concentration }\left[\frac{\mathrm{ngTEQ}}{\mathrm{kg}}\right]\right)
\end{aligned}
$$

Then, according to the depth of incorporation, a dilution factor is applied to calculate the impact of the fertilization scenario on the dioxin content of the soil. Without incorporation, it is assumed that natural processes incorporate the fertilizers in the upper $5 \mathrm{~cm}$. Otherwise, fertilizers are typically incorporated in the upper $30 \mathrm{~cm}$ through plowing. After one year of fertilization, the dioxin content in the soil will be increased by the quantity of dioxin added divided by the quantity of soil available for dilution (see Eq. (3)).

$$
\begin{aligned}
\text { Soil dioxin level }_{1}\left[\frac{\mathrm{ng} \mathrm{TEQ}}{\mathrm{kg} \mathrm{soil}}\right]= & \text { Soil dioxin level }{ }_{0}\left[\frac{\mathrm{ng} \mathrm{TEQ}}{\mathrm{kg} \mathrm{soil}}\right] \\
& +\left(\frac{\text { Dioxin input }\left[\frac{\mathrm{ng} \mathrm{TEQ}}{\mathrm{m}^{2}}\right]}{\text { Soil density }\left[\frac{\mathrm{kg}}{\mathrm{m}^{3}}\right] \times \text { Soil depth }[\mathrm{m}]}\right)
\end{aligned}
$$

In Eq. (3), the underscore 0 refers to the situation without fertilizers application (or before fertilizer application) and the underscore 1 refers to the situation after one year fertilizers application.

\subsubsection{Evaluation of the influence of fertilization practices on dioxin con- tent in food}

Two main categories of food are distinguished; vegetable and animal products. Vegetable products are considered to be exposed to dioxins through atmospheric depositions or through direct contact with liquid fertilizers while animals are exclusively exposed to dioxins through their diet, whereby soil is considered as a part of the diet. The proportion of soil and feedstuffs in the diet is evaluated differently for animals reared indoor and for animals reared outdoor (indoor reared animals are supposed to be raised inside buildings, without access to the outside). For outdoor rearing, fertilizers are supposed to be spread on meadows without plowing while for indoor rearing, fertilizers are supposed to be spread on soils and incorporated (crops). For liquid fertilizers applied on plant aerial parts (stem and leaves), we consider that $5 \%$ of the fertilizer is kept by the leaves instead of going straight to the soil (McLachlan et al., 1996). The dioxins found in these $5 \%$ are thus directly present in the feedstuffs ingested by the animals.
Dioxin levels of the diet are then calculated in Eq. (4) according to both feed and soil diet ratio and levels of dioxins (weighted average). Diet proportion is a number varying between 0 and 1 that describes, for each component of the animal diet, the relative part of the diet dry weight.

Diet dioxin level $\left[\frac{\mathrm{ng} \text { TEQ }}{\mathrm{kg}}\right]=\sum\left(\right.$ Diet proportion $\times$ Dioxin level $\left.\left[\frac{\mathrm{ng} \text { TEQ }}{\mathrm{kg}}\right]\right)$

The basic hypothesis for this step is that for each animal, the dioxin content of the animal products (eggs, milk or meat) is directly proportional to the amount of dioxins in the animal diet (see Eq. (5)). Any modification of the animal diet dioxin concentration will therefore directly generate a proportional modification of the animal products dioxin content. This equation is only valid under the hypothesis that the dioxin concentration in fat is directly proportional to the dioxin content in feed and/or soil and does not take into consideration any possible change in the animal fat content. In Eq. (5), the subscript 0 refers to the situation without fertilizers application (or before fertilizer application) and the subscript 1 refers to the situation after one year fertilizers application.

$$
\begin{aligned}
& \frac{\text { Animal diet dioxin level }_{1}\left[\frac{\mathrm{ng} \mathrm{TEQ}}{\mathrm{kg}}\right]}{\text { Animal diet dioxin level }_{0}\left[\frac{\mathrm{ng} \mathrm{TEQ}}{\mathrm{kg}}\right]} \\
& =\frac{\text { Concentration in animal products }_{1}\left[\frac{\mathrm{pg} \mathrm{TEQ}}{\mathrm{g}}\right]}{\text { Concentration in animal products }_{0}\left[\frac{\mathrm{pg} \mathrm{TEQ}}{\mathrm{g}}\right]}
\end{aligned}
$$

\subsubsection{Comparison of human dioxin intake for various fertilization} practices

The impact of fertilization practices on the human daily intake of dioxin is assessed considering human diet and dioxin contamination of foodstuffs. It is considered that fish, cereals, fruits and vegetables dioxin levels are unaffected by fertilization practices. Eq. (6) is used to calculate the daily human dioxin intake. For each foodstuff, the average consumption is multiplied by the typical dioxin contamination. Then, the sum of all the intakes represents the total dioxin intake.

$\begin{aligned} \text { Human daily dioxin intake }\left[\frac{\mathrm{pg} \text { TEQ }}{\text { day }}\right]= & \sum\left(\text { Food consumption }\left[\frac{\mathrm{g}}{\mathrm{day}}\right]\right. \\ & \left.\times \text { Food dioxin level }\left[\frac{\mathrm{pg} \text { TEQ }}{\mathrm{g}}\right]\right)\end{aligned}$

For Belgium, typical human diet composition is taken from Focant et al. (2002) while typical food dioxin contamination levels are taken from Windal et al. (2010).

\subsection{Maximum tolerable dioxin inputs (MTI)}

Dioxin inputs are considered acceptable on the long run if they do not cause dioxin accumulation in soils. This situation is only encountered when degradation rates exceed inputs. Annual decrease rates are linked to the half-life ( $\left.\mathrm{t}_{1 / 2}\right)$ according to Eq. ( 7$)$ and MTIs are calculated for 3 incorporation depth and three half-lives according to Eq. (8). Half-lives are given in years. Eq. (7) calculates the dioxin degradation in soils after one year assuming an exponential decay 
and a typical initial soil contamination of $3.4 \mathrm{ng} \mathrm{TEQ} / \mathrm{kg}$. Eq. (8) calculates the quantity of dioxin per surface unit that is degraded after one year.

Annual decrease ratio $=1-e^{-\frac{1 \mathrm{n}(2)}{t_{1 / 2}}}$

$$
\begin{aligned}
\operatorname{MTI}\left[\frac{\mathrm{ng} \text { TEQ}}{\mathrm{m}^{2}}\right]= & \frac{\text { Annual decrease ratio[\%] }}{100} \\
& \times \text { Soil dioxin level }\left[\frac{\mathrm{ng} \text { TEQ }}{\mathrm{kg}}\right] \times \text { Soil density }\left[\frac{\mathrm{kg}}{\mathrm{m}^{3}}\right] \\
& \times \text { Incorporation depth }[\mathrm{m}]
\end{aligned}
$$

\section{Data}

Inputs have been obtained from various sources. Information on dioxin levels in fertilizers are reported in Appendix A and summarized in Table 1. These data were obtained in literature from the last 12 years, whereby studies including very few samples were discarded. Fertilizer contamination levels are averages of median values. When no median data were available, means were considered. DLPCB contamination data was only available for a limited number of matrices only. Missing DL-PCB data were calculated on basis of the PCDD/F levels, assuming that DL-PCB levels should account for $1 / 3$ of the total dioxin contamination. This assumption is in agreement with the figures commonly encountered in the literature, although no consensus on the DL-PCB part of the total dioxin content could be found. For comparison, Kerst et al. (2003) reported that, on average, DL-PCBs represent $30 \%$ of the total dioxin contamination for compost and 55\% for sludge while in our compiled data DL-PCBs represent $13 \%$ of the total dioxin contamination for compost and $28 \%$ for sludge. For the sake of clarity, all TEQ systems (I-TEQ WHO,98-TEQ WHO,05-TEQ and N-TEQ) are considered to be equivalent and are therefore merely referred to as TEQ, without distinction.

We assume an animal diet exclusively composed of vegetative feedstuffs and soil. The soil accounting for, respectively, $0.5 \%$ or $6 \%$ of the dry matter ingested for animals reared indoor or outdoor, no matter the species (Fries et al., 1982; Fries, 1996; Wild et al., 1994). Here, we work with a typical dioxin contamination of 0.29 ng TEQ $\mathrm{kg} 88 \% \mathrm{dw}$ for vegetative feedstuff and of $3.43 \mathrm{ng} \mathrm{TEQ} / \mathrm{kg}$ dw for soil (EFSA, 2010; Table 1).When dealing with liquid fertilizers sprayed on plant leaves data were adapted. Under these conditions, it is assumed that the fertilizers are homogeneously applied and represent $5 \%$ of the vegetative feed material (Wild et al., 1994). Descriptive statistics about fertilizer compositions and uses at territory scale are presented in Table 2. Throughout the study, we consider a soil with a density of $1.6 \mathrm{t} / \mathrm{m}^{3}$, initially containing $3.4 \mathrm{ng} \mathrm{TEQ} / \mathrm{kg} \mathrm{dw}$.

Table 3 shows the human dioxin dietary intake values used in this study.

\begin{tabular}{|c|c|c|c|}
\hline \multirow[t]{2}{*}{ Products } & \multirow{2}{*}{$\frac{\mathrm{PCDD} / \mathrm{PCDF}}{\mathrm{ng} \mathrm{TEQ} / \mathrm{kg} \mathrm{dw}}$} & \multirow{2}{*}{$\frac{\text { DL-PCB }}{\text { ng TEQ/kg dw }}$} & \multirow{2}{*}{$\frac{\mathrm{PCDD} / \mathrm{PCDF}+\mathrm{DL}-\mathrm{PCB}}{\mathrm{ng} \mathrm{TEQ} / \mathrm{kg} \mathrm{dw}}$} \\
\hline & & & \\
\hline Manure & $0.6(2,16)^{\mathrm{a}}$ & $0.3^{\mathrm{b}}$ & 0.94 \\
\hline Sludge & $15.9(\mathbf{9}, \mathbf{3 2 5})$ & $6.2(4, \underline{126})$ & 22.1 \\
\hline Compost & $18.1(\mathbf{6}, \overline{431})$ & $2.7(4, \overline{58)}$ & 20.8 \\
\hline Digestate & $2.7(2,7)$ & $4.0(2, \overline{7})$ & 6.7 \\
\hline NPK fertilizers & $1.3(2,17)$ & $0.7^{\mathrm{b}}-$ & 2.0 \\
\hline Liming materials & $0.4(1, \overline{1})$ & $0.2^{\mathrm{b}}$ & 0.6 \\
\hline Belgian Agricultural Soils & $2.3(2, \overline{6})$ & $1.1^{\mathrm{b}}$ & 3.4 \\
\hline
\end{tabular}

Table 1

Overview of average dioxin levels for fertilizers and Belgian agricultural soils.

${ }^{a}$ Figures between brackets refer respectively to the number of studies and the number of samples involved.

b No data available, default DL-PCB levels were set at $1 / 3$ of the total dioxins level.

\begin{tabular}{|c|c|c|c|c|c|}
\hline & \multicolumn{4}{|l|}{ Composition } & \multirow{3}{*}{$\begin{array}{l}\begin{array}{l}\text { Belgian } \\
\text { consumption }\end{array} \\
\times 10^{3} \mathrm{~T} \mathrm{dw}\end{array}$} \\
\hline & \multirow{2}{*}{$\frac{\mathrm{N}}{\mathrm{kg} / \text { ton } \mathrm{ww}}$} & \multirow{2}{*}{$\frac{\mathrm{P}_{2} \mathrm{O}_{5}}{\mathrm{~kg} / \text { ton ww }}$} & \multirow{2}{*}{$\frac{\mathrm{K}_{2} \mathrm{O}}{\mathrm{kg} / \text { ton } \mathrm{ww}}$} & \multirow{2}{*}{$\frac{\mathrm{DW}}{\%}$} & \\
\hline & & & & & \\
\hline Manure & $5^{a}$ & $2.5^{\mathrm{a}}$ & $7.5^{a}$ & $20^{a}$ & $4456^{\mathrm{b}}$ \\
\hline Sludge & $6.8^{\mathrm{a}}$ & $8^{a}$ & $2.1^{\mathrm{a}}$ & $25^{a}$ & $116^{\mathrm{c}}$ \\
\hline Compost & $10^{\mathrm{d}}$ & $4^{d}$ & $6^{d}$ & $55^{d}$ & $61,6^{\mathrm{d}, \mathrm{e}}$ \\
\hline Digestate & $4^{\mathrm{f}}$ & $2^{f}$ & $4^{\mathrm{f}}$ & $5^{f}$ & No data \\
\hline NPK Fertilizer & / & / & 1 & 100 & $267^{g}$ \\
\hline Liming material & 0 & 0 & 0 & 100 & No Data \\
\hline \multicolumn{6}{|c|}{$\begin{array}{l}\text { a } \text { Destain, } 2008 . \\
\text { b Calculations based FPS, } 2010 \text { and on Nitrawal, } 2011 . \\
\text { c FPS, 2010, unpublished data. } \\
\text { d Service public de Wallonie, DGARNE (Division Générale de l'Agriculture des }\end{array}$} \\
\hline \multicolumn{6}{|c|}{$\begin{array}{l}\text { Ressources Naturelles et de l'Environnement); 2010, unpublished data. } \\
\text { e VLACO, } 2009 . \\
\text { f Agraost, 2007. } \\
\text { g IFA, 2011. }\end{array}$} \\
\hline
\end{tabular}

Table 2

Belgian fertilizers composition and annual consumption.

\section{Results}

\subsection{Impact at the Belgian scale}

The estimated amount of fertilizer dioxins (PCDD/Fs + DL-PCBs) spread annually on Belgian agricultural soils at territory scale is plotted in Fig. 2. No accurate data are available for the application of liming materials and digestate in Belgium. Hence these products are not included in Fig. 2.

Annual inputs at the Belgian scale were calculated using Eq. (1) and roughly represented $9 \mathrm{gTEQ} /$ year from which about half is supplied by manure. For comparison, the total atmospheric dioxin depositions on agricultural soils are set equal to $33.6 \mathrm{gTEQ} / \mathrm{year}$ (for PCDDs, PCDFs and PCB 126), considering $15351 \mathrm{~km}^{2}$ of agricultural soils in Belgium and average depositions of $6 \mathrm{pg}$ WHO-TEQ $/ \mathrm{m}^{2}$ day (FPS, 2010; VMM, 2010). Atmospheric depositions were, however, measured close to pollution sources and are probably overestimated.

\subsection{Selection of fertilization scenarios}

Two main categories of agricultural land use were selected: meadows and crops. For each category, all scenarios are tested. The various scenarios give us a range of values that better represent to real situation as fertilization practices are in practice so highly variable. Table 4 gives fertilizer application rates calculated for each scenario.

Table 3

Human dietary intake of PCDD/Fs and DL-PCBs in Belgium according to Focant et al. (2002).

\begin{tabular}{llll}
\hline & $\begin{array}{l}\text { Dioxin contamination } \\
\text { pg WHO-TEQ/g fat }\end{array}$ & $\begin{array}{l}\text { Consumption } \\
\text { rate g fat/day }^{\mathrm{b}}{ }^{\mathrm{a}}\end{array}$ & $\begin{array}{l}\text { Estimated daily } \\
\text { intake pg TEQ/day }^{\mathrm{c}}\end{array}$ \\
\hline Horse & 5.53 & 0.23 & 1.27 \\
Sheep & 1.85 & 0.68 & 1.25 \\
Beef & 1.78 & 4.80 & 8.54 \\
Milk and dairy & 1.74 & 20.56 & 35.77 \\
Pork & 0.28 & 11.41 & 3.19 \\
Chicken & 0.81 & 1.55 & 1.25 \\
Eggs & 0.64 & 2.66 & 1.7 \\
Fish and seafood & $12.38^{\mathrm{d}}$ & 0.71 & 8.79 \\
Total & & & 61.79 \\
\hline
\end{tabular}

Considering a fish and seafood fat ingestion of $0.71 \mathrm{~g} /$ day (Focant et al., 2002).

a Windal et al., 2010.

b Focant et al., 2002.

c Dioxin contamination $\times$ Consumption rate.

d Calculation based on Windal et al. 2010. 


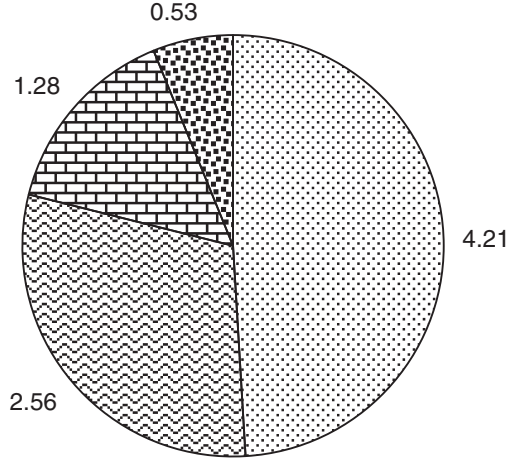

$\square$ Manure

$\otimes$ Sludge

曰 Compost

NPK fertilizers

Fig. 2. Dioxins inputs to Belgian agricultural soils (g TEQ/year).

\subsection{Transfer to soil}

Transfer of dioxin from fertilizers to soil is presented in Fig. 3. In this figure, an input of dioxin to agricultural soils is associated with each fertilization scenario, for meadows as well as for crops. Moreover, the inputs are directly proportional to the soil dioxin contamination, represented as second axis. In this case, we represent the soil dioxin contamination for an incorporation depth of $30 \mathrm{~cm}$ but for some special applications (for example non-plough methods, and free-range hens, ...) a thinner soil layer may be considered (e.g. the $5 \mathrm{~cm}$ surface soil) and the dioxin concentration will be adjusted accordingly. For comparison, annual atmospheric depositions are plotted at the right. Inputs on meadows and on crops are quite similar for each scenario at the exception of the sludge scenario. We can see that mineral fertilizers, common fertilization practices or manure bring less than $1 \mathrm{ng} \mathrm{TEQ} / \mathrm{m}^{2}$ while atmospheric depositions or digestate bring between 1 and $3 \mathrm{ng} \mathrm{TEQ} / \mathrm{m}^{2}$ and sludge or compost bring more than $3 \mathrm{ng} \mathrm{TEQ} / \mathrm{m}^{2}$.

\subsection{Transfer to the food chain}

The impact of fertilization practices on the dioxin content of animal products is displayed in Fig. 4 for solid and liquid fertilizers. Fish and consumption plant dioxin contents are believed to be unaffected by fertilization practices. Application methods play a critical role when dealing with dioxin transfer to soil. For the application of solid fertilizers, the only way animal dioxin ingestion is affected by fertilization practices is through the ingestion of contaminated soil. For liquid products sprayed on the plant aerial parts, we consider that a small amount of product remains on the vegetation. Calculation of the transfer of dioxin from soil or fertilizers to the food chain is based on Eqs. (4) and (5).

The dioxin ingestion increase linked to fertilization practices is one to two orders of magnitude higher for free-range animals than for animals reared indoor. Although evident, the difference between both rearing methods is of low interest with less than a $1 \%$ increase of the total diet dioxin levels for each scenario with the exception of the compost scenario. For liquid fertilizers sprayed on plant aerial parts, results are totally different. This practice can increase animal

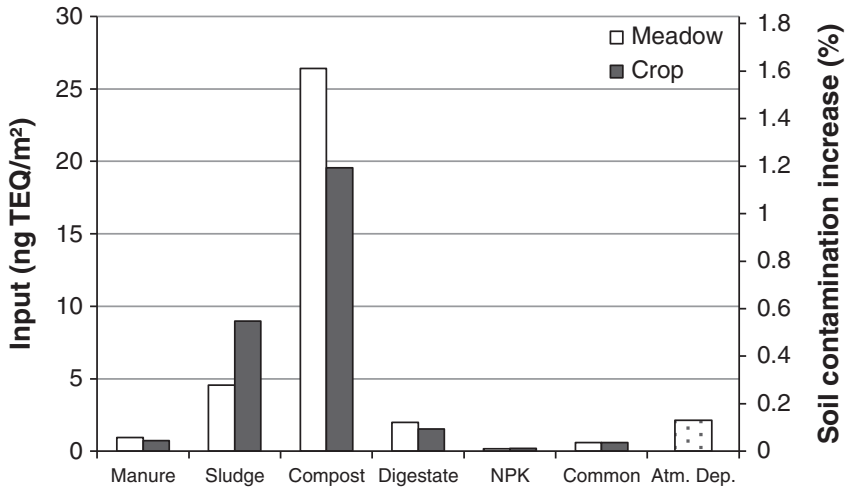

Fig. 3. Dioxin inputs after one year fertilization. Each column height can be read at the same time on the left axis (absolute value) and on the right axis (comparison with the soil dioxin content assuming an incorporation depth of $30 \mathrm{~cm}$ ).

fat dioxin content by 6 to $296 \%$ according to the fertilizer applied and the rearing environment.

\subsection{Potential impact on human dioxin intake}

Increases in human dioxin intake linked to each scenario are found in Table 5. All calculations are made using Eq. (6). Calculated increases range from 0 to $3.3 \%$ solid fertilizers and from 4.9 to $254 \%$ for liquid fertilizers. Moreover, results are highly dependent of the rearing method. For the conventional rearing method, we consider that grazing animals (bovine, equine, and ovine) are reared outdoor while non-grazing animals (pigs and poultry) are reared indoor.

Common fertilization practices and fertilization with solid products have little impact on human dioxin intake. However, some practices, like spraying liquid fertilizers on aerial parts of plants, could somewhat influence human dioxin intake. It is important to underline here that in every scenario, we assume that $100 \%$ of our diet consists of foodstuffs cultivated or bred on soils fertilized according to the considered scenario. When reading this table we need to keep in mind that the average contamination is given by the common scenario and that all other scenarios correspond to specific conditions which may not occur likely.

\subsection{Impact of multi-year fertilization practices}

The method presented above describes the impact of a single year fertilizers use. As PCDD/Fs and DL-PCBs are persistent in the environment, an assessment of the impact of several years of fertilization practices is needed. Data about half-life are congener specific and vary widely according to local conditions. Estimates are ranging from years to decades according to a study by Bodénan and Garrido (2004). Three half-life values, considered as a lower bound, an average and an upper bound, are proposed.

The MTI is calculated from the half-life using Eqs. (7) and (8). The results, presented in Table 6 , represent the maximum quantity of dioxin which could be added to soils annually without increasing the soil dioxin content.

Table 4

Description of the scenarios selected for meadows (crops) [ $\mathrm{kg} \mathrm{dw} / \mathrm{ha}]$.

\begin{tabular}{|c|c|c|c|c|c|c|}
\hline & Manure scenario & Sludge scenario & Compost scenario & Digestate scenario & NPK scenario & Common scenario \\
\hline Manure & $9200(6800)^{a}$ & 0 & 0 & 0 & 0 & 2903 \\
\hline Sludge & 0 & $2000(4000)$ & 0 & 0 & 0 & 76 \\
\hline Compost & 0 & 0 & $12650(9350)$ & 0 & 0 & 40 \\
\hline Digestate & 0 & 0 & 0 & 2875 (2125) & 0 & 0 \\
\hline NPK fertilizers & $120(150)$ & $515(433)$ & $190(320)$ & $120(235)$ & $650(660)$ & 174 \\
\hline Liming materials & 862 & 862 & 862 & 862 & 862 & 862 \\
\hline
\end{tabular}

\footnotetext{
${ }^{a}$ Crops' values are written in brackets when different from meadows.
} 
A

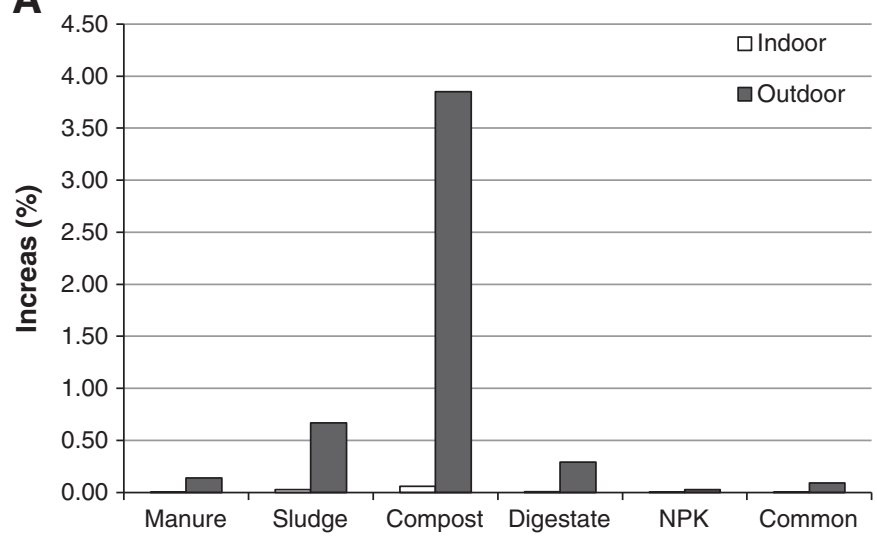

B

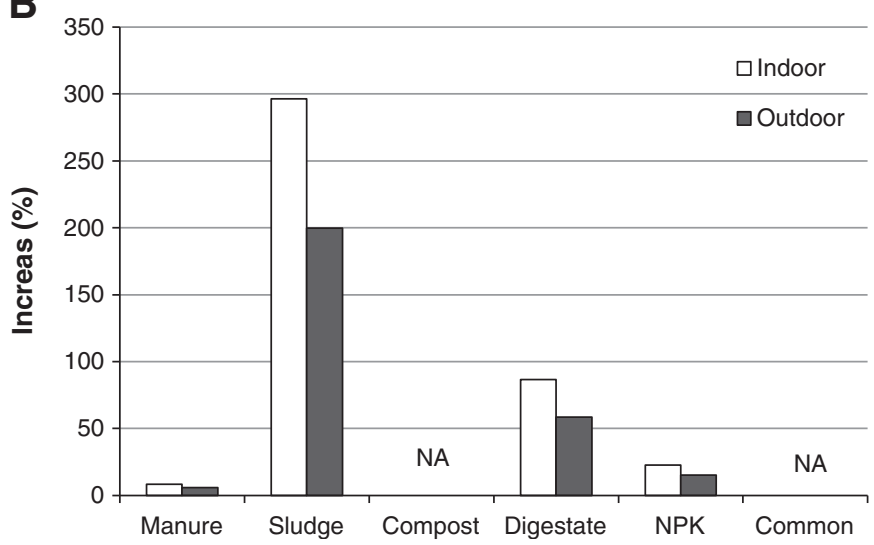

Fig. 4. Increase of dioxin levels in animal fat linked to fertilization practices: (A) solid fertilizers and (B) liquid fertilizers [NA $=$ non applicable].

\section{Discussion}

The method here proposed is designed to assess the dietary intake of dioxins by the general population and does not consider accidental contamination of fertilizers nor occupational exposure.

The dioxin level in animal products (meat, eggs, and milk) is linked to the dioxin content in the feed by a linear relationship (Hoogenboom et al., 2006; Rideout and Teschke, 2004; Van Overmeire et al., 2009). While for animals reared indoor, the ingestion of dioxins is mainly linked to feedstuffs ingestion, animals reared outdoor ingest significant amounts of soil ranging from 0.5 to $~ 8 \%$ of the dry weight ingested (Fries, 1996). Moreover, the relative bioavailability of dioxins present in soils ranges, according to studies and animal species, from 2 to 100\% compared to vegetal fat (SRC Inc., 2010). This

\section{Table 5}

Impact of fertilizer use on human intake of dioxins for different animal rearing methods (\%).

\begin{tabular}{lllll}
\hline Rearing method & & Outdoor & Indoor & Conventional* \\
\cline { 1 - 1 } Fertilizer use & & & & \\
\hline Spread on soil & Manure & +0.12 & +0.00 & +0.10 \\
& Sludge & +0.57 & +0.02 & +0.51 \\
& Compost & +3.30 & +0.05 & +2.93 \\
& Digestate & +0.25 & +0.00 & +0.22 \\
& NPK & +0.02 & +0.00 & +0.02 \\
& Common & +0.08 & +0.00 & +0.07 \\
Sprayed on plant aerial parts & Liquid & +171.25 & +254.15 & +180.88 \\
& sludge & & & \\
& Digestate & +50.19 & +74.36 & +53.00 \\
& NPK & +13.12 & +19.50 & +13.86 \\
& Manure & +4.90 & +7.12 & +5.16 \\
\hline
\end{tabular}

*Conventional $=$ grazing animal outdoor and non-grazing animals indoor.
Table 6

Dioxins MTI according to incorporation depth and half-life time of dioxins in soil.

\begin{tabular}{lllll}
\hline \multirow{2}{*}{$\begin{array}{l}\text { Half-life } \\
\text { years }\end{array}$} & $\begin{array}{l}\text { Annual } \\
\text { decrease } \%\end{array}$ & \multicolumn{3}{l}{ Maximum tolerable input $\left(\mathrm{pg} \mathrm{TEQ} / \mathrm{m}^{2}\right)$} \\
\cline { 3 - 5 } & & Depth $=5 \mathrm{~cm}$ & Depth $=15 \mathrm{~cm}$ & Depth $=30 \mathrm{~cm}$ \\
\hline $2^{\text {a }}$ & 29.29 & 79667 & 239001 & 478002 \\
$13^{\mathrm{b}}$ & 5.22 & 14196 & 42587 & 85174 \\
$54^{\mathrm{c}}$ & 1.28 & 3469 & 10407 & 20815 \\
\hline a & & & \\
b & Wild et al., 1994. & & \\
${ }^{c}$ & Average calculated from Sinkkone and Paasivirta, 2000.
\end{tabular}

huge variability forced us to consider the worst case which is a $100 \%$ relative bioavailability.

For liquid fertilization, we assume that the amount of dioxin (5\%) that is captured by the leaves during the treatment will remain there until the plant is eaten. This is a probably a worst case scenario. Data from the Vietnam War, however, show that when Agent Orange was spread on vegetation, TCDD was absorbed within minutes by the wax layer of the leaf cuticle. Then, the TCDD adhering to or absorbed by this layer could not be physically dislodged anymore (Young et al., 2004). Moreover, data about photodegradation of dioxin is often conflicting with half-lives ranging from hours to more than six weeks (McLachlan et al., 1996; Schuler et al., 1998; Niu et al., 2003). This clearly shows that there is a lack of knowledge about the fate of dioxins in contact with leaves or other plant part and that 5\% incorporation into the plant biomass is not necessarily an unrealistic case.

The calculation of a Maximum Tolerable Input (MTI) allows easy detection of the fertilization practices which, if systematically applied, would increase the soil dioxin levels over time. For inputs exceeding the MTI, the amount of added dioxin is higher than the amount which is annually degraded and the soil dioxin content will increase. However, this approach considers that the half-lives of dioxins in soil are not affected by their origin; dioxins brought by fertilizers have the same half-live as the dioxins already present in the soil.

At the Belgian scale, the total PCDD/Fs and DL-PCBs inputs to agricultural soils through fertilizing materials are estimated to be about 9 $\mathrm{g}$ TEQ/year, of which more than three quarters is linked to manure and sludge application. This input is four times smaller than atmospheric depositions meaning that $20 \%$ of the dioxin input to agricultural soils is caused by fertilization practices.

At field scale we observe huge variations in contamination levels between scenarios, inputs range from an order of magnitude under (NPK) to an order of magnitude above (compost) atmospheric depositions according to the fertilizing scenario. Moreover, the soil contamination increase in percent is multiplied by 6 for the same fertilization practice if the incorporation depth is of $5 \mathrm{~cm}$ instead of $30 \mathrm{~cm}$.

The transfer of dioxins from fertilizers to the food chain is rather limited. No scenario using solid fertilizers increases animal dioxin ingestion in a significant way. Liquid fertilizers, on the contrary, strongly increase animal dioxin ingestion. However, their use on plant aerial parts is rather scarce, except for the nitrogen solution which is commonly sprayed on forages. One has to keep in mind that, because of a lack of data, liquid fertilizers are supposed to be spread on soils and not on vegetation in the common scenario.

Three estimations of the dioxin daily intake of the Belgian population are available to our knowledge. A first one from Focant et al. (2002), proposing an average ingestion of $2.04 \mathrm{pg} \mathrm{TEQ} / \mathrm{kg}_{\mathrm{bw}}$ day, a second one from Bilau et al. (2008), proposing an average ingestion of $1.74 \mathrm{pg}$ CALUX-TEQ $/ \mathrm{kg}_{\mathrm{bw}}$ day and finally, one from Windal et al. (2010), proposing an average ingestion of $0.72 \mathrm{pg} \mathrm{TEQ} / \mathrm{kg}_{\mathrm{bw}}$ day. Data for Belgian dioxin ingestion used in this study are based partly on Focant et al. (2002) and partly on Windal et al. (2010). We worked with the dietary data from Focant et al. (2002) because they are based on agricultural productions (raw products) and not on food consumption 
(processed products) but we used the food dioxin levels from Windal et al. (2010) because they consider all the DL-PCBs and not only the nonortho PCBs.

The values for the increase of the human daily intake of dioxins due to fertilizers application are low for scenarios based on solid fertilizers (up to $+3.30 \%$ ) and high for scenarios including liquid fertilizers (from +4.90 to $+254.15 \%$ ). Moreover, when fertilizers are spread on soils, the increase in dioxin ingestion is higher for animals reared outdoor than for animals reared indoor or in a conventional way (grazing animals reared outdoor and non-grazing animals reared indoor). This situation is linked to the greater ingestion of soil and associated fertilizers for animals reared outdoor. On the other hand, for liquid fertilizers sprayed on plants, the increase in dioxin intake is higher for foodstuffs coming from indoor rearing than for those coming from conventional or outdoor rearing practices. This is linked to a lower background contamination for indoor rearing (less soil ingested) and thus to a stronger relative increase.

For comparison, the increase of the human daily intake of dioxin linked to the use of sludge calculated here is close to the one obtained by Wild et al. (1994). In a worst case, sludge application to agricultural soils with incorporation into soil could only increase the human dioxin intake by less than $1 \%$. However, if we consider that the sludge is sprayed and sticks to the plants, then human dioxin intake could increase by $49 \%$ according to Wild et al. and by $181 \%$ (assuming conventional rearing) according to this study.

The impact of multi-year fertilization on the soil dioxin content is estimated using a maximum tolerable input (MTI) that represents the maximum quantity of dioxin that may be added annually to soils without increasing their dioxin content. This input can be compared to the dioxin input linked to each scenario (see Fig. 3). Concerning the half-life time of two years, none of the scenarios could cause an increase of the soil dioxin content. Concerning the half-life time of 13 years, systematic application of compost without incorporation could increase soil dioxin content over time but no increase is expected as a consequence of the other fertilization practices. And finally, concerning the half-life of 54 years, the use of sludge or compost could, for various incorporation depths, increase soil dioxin content over time. When the input exceeds the MTI a maximum frequency of application permitting safe use can be calculated (Input/ MTI). For instance, in order to avoid increasing soil dioxin levels on meadows, without incorporation, compost shouldn't be applied more than once per two years for an average half-life ( 13 years). It also indicates that, in most of the situations, there is no risk of increasing the soil dioxin content on the long term and that risk assessment on a one year basis is relevant.

Data about the impact of several years of fertilization practices are often conflicting. Fouchécourt and Beausoleil (2001) estimate that after 100 years of sludge use, soil dioxin levels would increase by $5 \%$ at usual fertilization rates and by up to $10 \%$ for the worst case, whereas a review from Rideout and Teschke (2004) reported some cases where soil PCDD/F levels are increased by a factor of 7.1 after decades of sludge application.

\section{Conclusions}

The method presented in this paper is a practical and simple way for assessing the impact of agricultural practices on human dioxin daily intake. Comparisons between fertilization practices are possible at each step of the process. However, results are dependent on the initial assumptions and, at the same time, data about dioxin levels in soil, fertilizing products, food and feedstuffs are often conflicting. Further work would allow a more accurate risk assessment. At the moment, very little information is available on the degradation rates of the dioxins sprayed on the plants and on the part that will remain on the vegetation or run-off to the soil. In the same way, information about dioxin relative bioavailability in soils and on plant foliage is often conflicting. Nevertheless, this method can be useful when assessing the relative contribution of fertilization practices on soil and foodstuffs dioxin levels.

Potential dioxin inputs linked to fertilizers, sludge and soil conditioners are highly variable. Mineral products have generally low dioxin contents and are applied at low rates while products made of organic matter have higher dioxin content and are applied at higher rates. One remarkable exception is manure which is but slightly contaminated. As a result, a plot fertilized with compost receives about one hundred times more dioxins than a plot fertilized with chemical fertilizers. Despite this, we estimate that dioxin levels in foodstuffs are generally only slightly impacted by fertilization practices.

The main and possibly only practice that could lead to higher human dioxin intake is the spraying of liquid fertilizers on plant aerial parts, which is an uncommon practice for liquid sludge, digestate and manure but is a common practice for nitrogen solution and specialty products containing micronutrients. Considering an average half-life for dioxins in soil, it appears that the risk of increasing soil dioxin levels through fertilization practices is limited.

\section{Acknowledgments}

This study was funded by the Federal Public Service of Health, Food Chain Safety and Environment (contract RT 10/01 FERTIDIOX).

\section{Appendix A. Supplementary data}

Supplementary data to this article can be found online at doi:10. 1016/j.scitotenv.2012.02.008.

\section{References}

Agraost. Valorisation agronomique du digestat [Internet]. Agraost ; 2007 Jun [Cited 2011 Jul 13]. Available from: http://www.glea.net/AGRAOST/doc/ValoragrondudigestatJourneedetude260607pdf.pdf.

AGW 12/01/95. Arrêté du Gouvernement wallon portant réglementation de l'utilisation sur ou dans les sols des boues d'épuration ou de boues issues de centres de traitement de gadoues de fosses septiques; 1995. Moniteur Belge, 1995 Apr 12.

Bilau M, Matthys C, Baeyens W, Bruckers L, De Backer G, Den Hond E, et al. Dietary exposure to dioxin-like compounds in three age groups: results from the Flemish environment and health study. Chemosphere 2008;70:584-92.

Bodénan F, Garrido F. Devenir des dioxines dans les sols - Analyse critique de données bibliographiques; 2004. BGRM; 2004 May. Report No. : RP-53070-FR. Contract No. : CV 03000012.

Brändli R, Kupper T, Bucheli T, Mayer J, Stadelmann FX, Tarradellas J. Occurrence and relevance of organic pollutants in compost, digestate and organic residues; literature review. EPF Lausanne - ENAC - ISTE - CECOTOX/Agroscope FAL Reckenholz; 2004 May; 2004.

Brandli R, Kupper T, Bucheli T, Zennegg M, Huber S, Ortelli D, et al. Organic pollutants in compost and digestate. Part 2. Polychlorinated dibenzo-p-dioxins, and -furans, dioxin-like polychlorinated biphenyls, brominated flame retardants, perfluorinated alkyl substances, pesticides, and other compounds. J Environ Monit 2007;9:465-72.

Brandling R, Bucheli T, Kupper T, Furrer R, Stadelmann F, Tarradellas J. Persistent organic pollutants in source-separated compost and its feedstock materials - a review of field studies. J Environ Qual 2005;34:735-60.

Destain JP. Matières fertilisantes. Gembloux Agro Bio-Tech; 2008. Cursus.

DGARNE (Direction Générale de l'Agriculture et des Ressources Naturelles et Environnement) Service Public de Wallonie, 15 avenue Prince de Liège 5100 - Jambes (Namur) Belgium.

EFSA (European Food Safety Authority). Results of the monitoring of dioxin levels in food and feed. EFSA J 2010;8:1385-421.

Eljarrat E, Caixach J, Rivera J. Decline in PCDD and PCDF levels in sewage sludges from Catalonia (Spain). Environ Sci Technol 1999;33:2493-8.

Eljarrat E, Caixach J, Rivera J. A comparison of TEQ contributions from PCDDs, PCDFs and dioxin-like PCBs in sewage sludges from Catalonia, Spain. Chemosphere 2003;51:595-601.

Erhardt W, Prüeß A. Organic contaminants in sewage sludge for agricultural use. UMEG Center for Environmental Measurements, Environmental Inventories and Product Safety; 2001 Oct; 2001. Sponsored by the European commission joint Research Centre.

European Commission. Communication from the commission to the council, the European parliament, the European economic and social committee on the implementation of the Community Strategy for dioxins, furans, and polychlorinated biphenyls (COM(2001)593) - Third progress report; 2010. Ref.: COM(2010) 562; 10 p. 
Focant JF, Eppe G, Pirard C, Massart AC, André JE, De Pauw E. Levels and congener distribution of PCDDs, PCDFs and non-ortho PCBs in Belgian foodstuffs assessment of dietary intake. Chemosphere 2002;48:167-79.

Fouchécourt MO, Beausoleil M. Evaluation des impacts à long terme de l'utilisation agricole de matières résiduelles fertilisantes au Québec - Mise en contexte et risques la santé associés à l'apport de dioxines/Furannes. Québec: INSPO (Institut national de santé publique du Québec); 2001. Mar.

FPS (Belgian Federal Public Service). General direction of statistics and economic information technology. Chiffres clés de l'agriculture; 2010. 2010.

Fries GF. Ingestion of sludge applied organic chemicals by animals. Sci Total Environ 1996; 185:93-108

Fries GF, Marrow GS, Snow PA. Soil ingestion by dairy cattle. J Dairy Sci 1982;65:611-8.

Fuentes J, Font R, Gomez-Rico F, Molto J. Multivariant statistical analysis of PCDD/FS in sewage sludges from different areas of the Valencian Community (Spain). Chemosphere 2007:67:1423-33.

Groeneveld E, Hébert M. Dioxines, furannes, BPC et HAP dans les composts de l'Est du Canada [Internet]. Développement durable, Environnement et Parcs, Québec; 2002 http://www.mddep.gouv.qc.ca/matieres/articles/compost.htm [Cited 2011 Jan 03] Available from :.

Hickox WH, Denton JE. Air Toxics Hot Spots Program: Technical Support Document for Exposure Assessment and Stochastic Analysis. Appendix G. California: Office of Environmental Health Hazard Assessment; 2000. Sep.

Hoogenboom LAP, Kan CA, Zeilmaker FJ, Van Eijkeren J, Traag WA. Carry-over of dioxins and PCBs from feed and soil to eggs at low contamination levels - influence of mycotoxin binders on the carry-over from feed to eggs. Food Addit Contam 2006;23:518-27.

Huelster A, Mueller J, Marschner H. Soil-plant transfer of polychlorinated dibenzo-pdioxins and dibenzofurans to vegetables of the cucumber family (Cucurbitaceae). Environ Sci Technol 1994;28:1110-5.

IFA (International Fertilization Agency). IFADATA [Internet]. [Cited 2011 Jan 04]. Available from: http://www.fertiliser.org/ifa/ifadata/search2011

Kerst M, Waller U, Peichl L, Bittl T, Reifenhäuser W, Körner W. Dioxin-like PCB in environmental samples in southern Germany. Fresenius Environ Bull 2003;12:511-6.

Kupper T, Brändli R, Bucheli T, van Slooten KB, Mayer J, Bachmann HJ, et al. Micropolluants organiques dans le compost et le digestat en Suisse [Internet]. Berne: Office fédéral de l'environnement; 2007 www.environnement-suisse.ch/uw-0743-f [Cited 2011 Sep 27]. Report No. : UW-0743-F. Available from:.

Martínez K, Abad E, Palacios O, Caixach J, Rivera J. Assessment of polychlorinated dibenzo-p-dioxins and dibenzofurans in sludges according to the European environmental policy. Environ Int 2007;33:1040-7.

McLachlan M, Horstmann M, Hinkel M. Polychlorinated dibenzo-p-dioxins and dibenzofurans in sewage sludge: sources and fate following sludge application to land. Sci Total Environ 1996;185:109-23.

Mestdecreet. Decreet houdende de bescherming van water tegen de verontreiniging door nitraten uit agrarische bronnen; 2006. p. 76368-401. Moniteur Belge, 2212-2006.

Nitrawal. Arrêté du Gouvernement wallon modifiant le Livre II du Code de l'Environnement contenant le Code de l'Eau en ce qui concerne la gestion durable de l'azote en agriculture; 2011. p. 25217-34. Moniteur Belge. 31-04-2011.

Niu J, Chen J, Henkelmann B, Quan X, Kettrup A, Schramm KW. Photodegradation of PCDD/Fs adsorbed on spruce (Picea abies (L.) Karst.) needles under sunlight irradiation. Chemosphere 2003;50:1217-25.

OVAM. (Openbare Afvalstoffenmaatschappij voor het Vlaamse Gewest). VLAREA; Vlaams reglement inzake afvalvoorkoming en -beheer. Mechelen: OVAM; 2005. Jun. Publication No.: D/2005/5024/13.

Paulsrud B, Wien A, Nedland KT. A Survey of Toxic Organics in Norwegian Sewage Sludge, Compost and Manure. Oslo (NO): Norwegian water technology Centre AS; 1999.

Rideout K, Teschke K. Potential for increase human foodborne exposure to PCDD/F when recycling sewage sludge on agricultural land. Environ Health Perspect 2004;112:959-69.

Rogowski D, Golding S, Dowhay D, Singleton S. Final report: screening survey for metals end dioxins in fertilizer products end soils in Washington State. Washington
(US): Washington Department of Ecology; 1999. Apr. Ecology publication No.: 99309.

Schuler F, Schmid P, Schlatter Ch. Photodegradation of polychlorinated dibenzop-dioxins and dibenzofurans in cuticular waxes of laurel cherry (Prunus laurocerasus). Chemosphere 1998;36(1):21-34.

Sinkkone S, Paasivirta J. Degradation half-life times of PCDDs, PCDFs and PCBs for environmental fate modeling. Chemosphere 2000;40:943-9.

SRC Inc. Final report: bioavailability of dioxins and dioxin-like compounds in soil [Internet]; 2010. 2010 Dec [Cited 2011 Sep 28]. Sponsored by US EPA. Available from: http://www.epa.gov/superfund/health/contaminants/dioxin/pdfs/Final_dioxin_RBA_ Report_12_20_10.pdf.

Stevens J, Jones K. Quantification of PCDD/F concentrations in animal manure and comparison of the effects of the application of cattle manure and sewage sludge to agricultural land on human exposure to PCDD/Fs. Chemosphere 2002;50: 1183-91.

Stevens J, Green N, Jones K. Survey of PCDD/Fs and non-ortho PCBs in UK sewage sludges. Chemosphere 2001;44:1455-62.

Stockholm Convention on Persistent Organic Pollutants. [Internet], [Cited 2012 February 3]. Available from: http://.pops.int/2008.

Uegaki R, Seike N, Otani T. Polychlorinated dibenzo-p-dioxins, dibenzofurans, and dioxin-like polychlorinated biphenyls in rice plants: Possible contaminated pathways. Chemosphere 2006;65:1537-43.

Van den Berg M, Birnbaum L, Bosveld AT, Brunström B, Cook P, et al. Toxic equivalency factors (TEFs) for PCBs, PCDDs, PCDFs for humans and wildlife. Environ Health Perspect 1998;106:775-92.

Van den Berg M, Birnbaum L, Denison M, De Vito M, Farland W, et al. The 2005 World Health Organization reevaluation of human and mammalian toxic equivalency factors for dioxins and dioxin-like compounds. Toxicol Sci 2006;93:223-41.

Van Gestel G, Engels R, Nouwen J, Cornelis C, Provoost J, Van Gestel G, et al. Voorstel voor normering van PCB's en PCDD/F's [Internet]. Openbare Afvalstoffenmaatschappij voor het Vlaamse Gewest; 2007. Jan [Cited 2011 Sep 28]. Available from: http://www.ovam.be.

Van Overmeire I, Waegeneers N, Sioen I, Bilau M, De Henauw S, Goeyens L, et al. PCDD/Fs and dioxin-like PCBs in home-produced eggs from Belgium: levels, contamination sources and health risks. Sci Total Environ 2009;407:4419-29.

VLACO (Vlaamse Compostorganisatie). Activiteitenverslag, 2009, [Internet]. 2009 [Cited 2011 Mei 20].Available from: http://www.vlaco.be/2009.

VMM (Vlaamse Milieumaatschappij). Dioxine- en PCB126-depositiemetingen in Vlaanderen in de periode april 2009-maart 2010. [Internet]. 2010 [Cited 2011 Aug 05]. Available from :http://www.vmm.be/pub2010.

WHO (World Health Organization). Oct. 23 - 27GEMS/Food Total Diet Studies: Report of the 4th International Workshop on Total Diet Studies. Beijing (CH): WHO; 2006 2007.

Wild SR, Harrad SJ, Jones C. The influence of sewage sludge applications to agricultural land on human exposure to polychlorinated dibenzo-p-dioxins (PCDDs) and -furans (PCDFs). Environ Pollut 1994;83:357-69.

Willemsen F. Report on the seafood consumption data found in the European countries of the OT-SAFE project WP3. Risk assessment of TBT in seafood in Europe. Amsterdam (NL: Institute for Environmental Studies; 2003. [Internet]; 2003 Nov. [Cited 2011 Sep 20]. Report No.: W-03/42.Contract No.: QLK1-CT- 2001-01437. Available from:http://www. ivm.vu.nl/en/Images/OT7DBA3C19-6B94-4471-BD772CB22C9544E7_tcm53-87248.pdf.

Windal I, Vandevijvere S, Maleki M, Goscinny S, Vinkx C, Focant JF, et al. Dietary intake of PCDD/Fs and dioxin-like PCBs of the Belgian population. Chemosphere 2010;79: 334-40.

Young A, Giesy P, Jones P, Newton M. Environmental fate and bioavailability of agent orange and its associated dioxin during the Vietnam War. Environ Sci Pollut Res 2004;11:359-70.

Zennegg M, Brändli R, Kupper T, Bucheli T, Gujer E, Schmid P, et al. PCDD/Fs, PCBs, PBDEs, TBBPA and HBCD in compost and digestate. Organohalogen Compd 2005;67:1040-3. 